JPPMS, Vol. 4, No. 1, 2020

Jurnal Penelitian Pendidikan Matematika dan Sains

http://journal.unesa.ac.id/index.php/jppms/

\title{
PENALARAN ALJABAR SISWA SMP DALAM MENYELESAIKAN SOAL POLA BILANGAN
}

\author{
Oleh: \\ Kartika Purwaningtyas ${ }^{l}$, Abdul Haris Rosyidi ${ }^{2}$ \\ Jurusan Matematika FMIPA Universitas Negeri Surabaya \\ kartikapurwaningtyas16030174015@unesa.ac.id \\ abdulharis@unesa.ac.id
}

\begin{abstract}
Abstrak - Penalaran aljabar merupakan proses berpikir logis untuk mencari dan mengenali pola dari suatu situasi tertentu kemudian membuat kesimpulan berupa generalisasi atas ide-ide matematika terkait situasi tersebut. Penelitian kualitatif ini bertujuan untuk mendeskripsikan penalaran aljabar siswa SMP dalam menyelesaikan soal pola bilangan. Subjek dalam penelitian ini adalah dua siswa kelas VIII dengan kriteria mampu menyelesaikan soal tes penalaran aljabar dan memiliki variasi jawaban yang berbeda. Kedua subjek memiliki karakteristik yaitu subjek pertama menyelesaikan soal dengan satu ide untuk menemukan aturan umum pola bilangan sedangkan subjek kedua menemukan gagasan baru untuk menemukan aturan umum pola bilangan.Teknik pengumpulan data pada penelitian ini yaitu menggunakan tes penalaran aljabar dan wawancara. Data yang terkumpul dianalisis berdasarkan indikator penalaran aljabar meliputi mencari pola, mengenali pola, dan generalisasi. Hasil penelitian menunjukkan siswa pada mencari pola diawali dengan mengidentifikasi unsur penyusun pola bilangan kemudian siswa menemukan hubungan tiap unsur pada pola bilangan. Pada tahap mengenali pola, siswa menyadari hubungan antar suku-suku ganjil dan suku-suku genap pada pola bilangan, kemudian melakukan percobaan-percobaan untuk menemukan rumus umum pola bilangan agar memudahkan mencari nilai tiap suku. Siswa menggunakan tabel dan melakukan pendataan tiap suku pada pola bilangan untuk menemukan rumus umum pola bilangan. Ada perbedaan cara untuk menemukan rumus umum, yaitu ada siswa yang menggunakan selisih antar suku, sedangkan siswa yang lain menggunakan selisih antara suku ganjil dengan ganjil dan suku genap dengan genap. Pada langkah akhir penalaran aljabar yaitu generalisasi siswa menarik kesimpulan dari proses yang dilakukannya di tahap sebelumnya.
\end{abstract}

Kata Kunci: penalaran, penalaran aljabar, pola bilangan.

Abstract - Algebraic reasoning is a process of logical thinking to search and recognize patterns of a particular situation and then make conclusions in the form of generalizations of mathematical ideas related to the situation. This qualitative research aims to describe the algebraic reasoning of junior high school students in solving numerical pattern problems. The subjects in this study were two eighth grade students with the criteria of being able to solve algebraic reasoning test questions and having different variations of answers. Both subjects have the characteristics of the first subject solving the problem with one idea to find general rules of number patterns while the second subject finds new ideas to find general rules of number patterns. Data collection techniques in this study are using algebraic reasoning tests and interviews. The collected data is analyzed based on algebraic reasoning indicators including finding patterns, recognizing patterns, and generalizing. The results showed students in looking for patterns beginning with identifying the constituent elements of number patterns then students find the relationship of each element in number patterns. In the stage of recognizing patterns, students realize the relationship between odd terms and even terms in number patterns, then conduct experiments to find general formulas for number patterns to make it easier to find the value of each term. Students use tables and collect data on each term in a number pattern to find a general formula for a number pattern. There are different ways to find a general formula, namely, there are students who use differences between tribes, while other students use the difference between odd and even terms and even terms with even numbers. In the final step of algebraic reasoning, the generalization of students draws conclusions from the processes they did in the previous stage.

Keywords: reasoning, algebraic reasoning, number patterns. 


\section{Pendahuluan}

Dalam permendiknas no 22 tahun 2006, salah satu tujuan diberikan mata pelajaran matematika pada siswa SMP yaitu agar siswa memiliki kemampuan untuk menggunakan penalaran pada pola dan sifat, melakukan manipulasi matematika dalam membuat generalisasi, dan menyusun bukti, atau menjelaskan gagasan dan pernyataan matematika. Pada kurikulum 2013, penalaran masih menjadi tuntutan di jenjang SMP. Hal ini tercantum dalam deskripsi kompetensi pengetahuan pada Permendikbud no 21 tahun 2016, yaitu menunjukkan keterampilan menalar, mengolah, dan menyaji.

Menurut Kobandaha (2019) penalaran merupakan bagian dari berpikir yang melampaui tingkat mengingat. Penalaran meliputi berpikir dasar, berpikir kritis, dan berpikir kreatif. Lohman \& Lakin (2011) menyatakan bahwa penalaran mengacu pada proses menarik kesimpulan berdasarkan informasi yang ada. Shadiq (2004: 2) menyatakan "penalaran merupakan suatu kegiatan, suatu proses atau suatu aktivitas berpikir untuk menarik kesimpulan atau membuat suatu pernyataan baru yang benar berdasar pada beberapa pernyataan yang kebenarannya telah dibuktikan atau diasumsikan sebelumnya". Dari beberapa pendapat tersebut dapat disimpulkan bahwa penalaran adalah proses berpikir logis untuk membuat kesimpulan dengan argumen yang disusun berdasarkan pengetahuan-pengetahuan sebelumnya.

Hubungan antara matematika dan penalaran dikemukakan oleh Ayal (2016: 52) yaitu matematika dan penalaran merupakan dua hal yang tidak bisa dipisahkan, materi matematika dipahami dengan penalaran dan penalaran dipraktikkan melalui pembelajaran matematika. Sukirwan dkk (2018) menyatakan bahwa penalaran merupakan salah satu aspek dari kemampuan matematika yang sangat penting dalam pelaksanaan pembelajaran sehingga penalaran menjadi kemampuan dasar yang dibutuhkan untuk mengembangkan kemampuan matematis lainnya.

Meskipun penalaran penting, namun fakta menunjukkan bahwa penalaran siswa di Indonesia masih rendah. Hal ini ditunjukkan oleh hasil TIMSS pada 2011 yang menunjukkan bahwa ratarata persentase hasil pada domain penalaran $17 \%$ dan pada domain aljabar $22 \%$ yang merupakan hasil paling rendah diantara empat domain dalam TIMSS (Rosnawati, 2013). Wardhani dan Rumiati (2011) menyatakan beberapa gambaran kemampuan matematika dari laporan hasil survey TIMSS menunjukkan siswa umumnya cukup baik dalam menyelesaikan soal yang berkaitan dengan konten baku dan keterampilan dasar namun lemah dalam mengerjakan soal-soal yang menuntut kemampuan penalaran aljabar, seperti mengenali pola bilangan. Penelitian lain oleh Rizta dkk (2013) menunjukkan dari 27 siswa hanya 29,630\% yang memiliki kemampuan penalaran baik dalam menjawab soal penalaran model TIMSS.

Dalam pembelajaran matematika, aljabar merupakan subjek yang masih dianggap sulit oleh siswa. Menurut Chow (2011) disamping pentingnya aljabar, banyak siswa masih menganggap aljabar abstrak dan sulit dipahami. Kesulitan yang ditemukan pada siswa salah satunya berkaitan dengan penalaran aljabar siswa yaitu generalisasi. Menurut Indraswari, Budayasa dan Ekawati (2018) faktanya banyak siswa kesulitan dalam mempelajari aljabar. Kesulitan siswa dalam belajar aljabar dapat diminimalisasi dengan mengidentifikasi penalaran aljabar siswa sehingga guru dapat mendesain pembelajaran yang dapat meningkatkan penalaran aljabar siswa. Hal ini juga berlaku pada pembelajaran pola bilangan, dimana Ariyanti dan Setiawan (2019) menyebutkan bahwa dalam menyelesaikan soal pola bilangan siswa kelas VIII kesulitan dalam menentukan pola yang ada pada soal dan merumuskan generalisasi dari pola bilangan. Kesulitan tersebut juga dapat diminimalisasi dengan mengidentifikasi penalaran aljabar.

Penalaran aljabar menurut Kaput \& Blanton (2005) adalah proses dimana siswa melakukan generalisasi atas ide matematika dalam situasi tertentu, membuat generalisasi melalui diskusi, dan mengekspresikannya secara formal sesuai tingkatan usia. Menurut Herbert dan Brown (2000) penalaran aljabar adalah proses mencari pola, mengenali pola, dan menggeneralisasi pola untuk memecahkan suatu masalah. Dari dua pendapat tersebut dapat disimpulkan bahwa penalaran aljabar merupakan proses berpikir logis untuk mencari pola dan mengenali pola dari suatu situasi tertentu kemudian membuat kesimpulan berupa generalisasi atas ide-ide matematika terkait situasi tersebut.

Beberapa penelitian tentang penalaran aljabar yang telah dilakukan antara lain tentang penalaran aljabar siswa SMP ditinjau dari gaya belajar siswa (Indraswari; 2017), penalaran aljabar siswa dengan kecerdasan logika-matematis dan visual-spasial (Kobandaha; 2019), penalaran aljabar siswa pada pola (Rivera dan Becker; 2009) yang merupakan hasil eksperimen pembelajaran, dan lainnya. Beberapa penelitian difokuskan kepada proses siswa menyelesaikan masalah aljabar atau masalah pola secara umum. Lepak, Wernet dan Ayieko (2018) menyatakan bahwa penalaran aljabar dapat diukur melalui tugas-tugas tertentu dengan melihat hasil pekerjaan siswa. Penelitian Rivera dan 
Becker (2009) menggunakan soal pola sebagai instrumen pengukur generalisasi aljabar, dalam penelitian tersebut disebutkan bahwa memecahkan pola memberikan siswa kesempatan untuk mengonstruk dan menjustifikasi generalisasi aljabar. Mouhayar dan Jurdak (2016) menyatakan bahwa menggeneralisasi pola merupakan acuan yang dijadikan peneliti-peneliti sebagai pendekatan untuk meningkatkan penalaran aljabar siswa. Pola bilangan merupakan salah satu cakupan pola pada aljabar yang di dalamnya melibatkan proses generalisasi. Maka dapat disimpulkan bahwa pemberian tugas pola bilangan dapat digunakan untuk mengukur penalaran aljabar siswa.

\section{Metode}

Penelitian ini merupakan penelitian kualitatif dengan tujuan untuk mendeskripsikan penalaran aljabar dalam menyelesaikan soal pola bilangan. Rancangan penelitian ini yaitu membuat proposal penelitian, membuat instrumen pendukung, mengambil data, menganalisis data, dan membuat laporan.

Sumber data dari penelitian ini adalah 17 siswa SMP kelas VIII. Karena akan terdapat beberapa perspektif siswa dalam menyelesaikan soal pola bilangan pada tes penalaran aljabar, untuk mengetahui penalaran aljabar siswa pengambilan subjek dalam penelitian ini dilakukan dengan pendekatan sampling variasi maksimal yaitu diawali dengan pemberian soal tes penalaran aljabar sebagai salah satu tahap sebelum penentuan subjek. Subjek dipilih berdasarkan ciri khas subjek dalam menyelesaikan soal tes, kemudian akan diidentifikasi penalaran aljabar masing- masing subjek tersebut.

Dari hasil tes penalaran aljabar yang diberikan, secara keseluruhan ditemukan dua tipe penyelesaian yang dilakukan siswa dalam menyelesaikan soal pola bilangan yaitu, tipe pertama, mengikuti ide awal untuk menentukan generalisasi, dan tipe ke dua, menemukan ide baru untuk menggeneralisasi pola bilangan. Oleh karena itu subjek yang dipilih dalam penelitian ini adalah 2 siswa yang mewakili masing-masing tipe/ Subjek S01 menyelesaikan soal dengan satu ide yang berpandu pada ide awal, sedangkan subjek S02 menemukan gagasan baru untuk menemukan aturan umum pola bilangan.

Setelah subjek penelitian ditetapkan, langkah selanjutnya adalah melakukan wawancara berbasis tugas tes penalaran aljabar. Wawancara dengan subjek penelitian dilakukan untuk menggali informasi dan memberikan gambaran yang lebih jelas mengenai penalaran aljabar siswa dalam menyelesaikan soal pola bilangan.

Data yang diperoleh dari hasil tes penalaran aljabar dan wawancara selanjutnya dianalisis berdasarkan indikator penalaran aljabar yang diadaptasi dari indikator penalaran aljabar oleh Herbert dan Brown (2000), Indraswari (2017) dan Kobandaha (2019) sebagai berikut.

Tabel 1. Indikator Penalaran Aljabar dalam Menyelesaikan Soal Pola Bilangan

\begin{tabular}{|c|c|c|}
\hline No & $\begin{array}{c}\text { Indikator penalaran } \\
\text { aljabar }\end{array}$ & Deskripsi \\
\hline 1 & $\begin{array}{c}\text { Mencai Pola } \\
\text { (Pattern seeking) }\end{array}$ & $\begin{array}{l}\text { a. Menentukan unsur-unsur } \\
\text { penyusun pola bilangan } \\
\text { b. Menemukan hubungan antara dua } \\
\text { unsur penyusun pola bilangan }\end{array}$ \\
\hline 2 & $\begin{array}{c}\text { Mengenali Pola } \\
\text { (Patten recognition) }\end{array}$ & $\begin{array}{l}\text { a. Menemukan kesamaan hubungan } \\
\text { setiap elemen penyusun pola } \\
\text { bilangan } \\
\text { b. Melakukan percobaan-percobaan } \\
\text { untuk menemukan aturan umum } \\
\text { pola bilangan }\end{array}$ \\
\hline 3 & $\begin{array}{c}\text { Generalisasi } \\
(\text { Generalization })\end{array}$ & $\begin{array}{l}\text { a. Menemukan aturan umum pola } \\
\text { bilangan }\end{array}$ \\
\hline
\end{tabular}

Soal tes penalaran ajabar yang diberikan kepada siswa adalah sebagai berikut. 
Diketahui pola bilangan sebagai berikut

$\begin{array}{llllllllll}3 & -1 & 5 & 1 & 7 & 3 & 9 & \ldots & \ldots\end{array}$

1. Tentukan dua suku berikutnya dari pola bilangan di atas!

2. Tentukan suku ke 100 dari pola bilangan di atas!

3. Dapatkah kamu menemukan rumus umum dari pola bilangan tersebut?

\section{Hasil dan Pembahasan \\ Subjek S01}

Subjek S01 menentukan unsur-unsur penyusun pola bilangan dan hubungan antar unsur dapat dilihat pada jawaban dan petikan wawancara berikut.

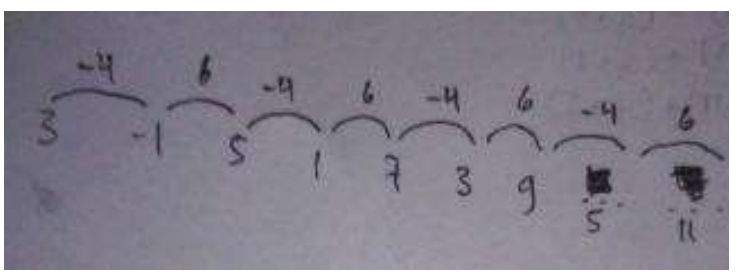

Gambar 1. Hasil Pekerjaan Subjek S01

$\mathrm{P}$ : Bagaimana caramu mengerjakan soal nomer 1 ?

S01 : Caranya $-1-3$ hasilnya -4 , terus 5-(-1) hasilnya $6,1-5$ hasilnya -4 .

$\mathrm{P} \quad$ : Kenapa kamu pake cara itu?

S01 : Dicari selisihnya

Subjek S01 mampu menentukan unsur-unsur penyusun pola bilangan. Hal ini dapat dilihat dari pemahaman subjek S01 atas pertanyaan soal nomor 1 yang meminta subjek untuk menentukan dua suku berikutnya dari pola bilangan. Subjek S01 mencari beda pola bilangan dengan mencari selisih tiap suku pada pola bilangan. Subjek S01 menemukan selisih tiap suku pada pola bilangan adalah -4 dan 6.

Kemudian subjek S01 menemukan bahwa pada pola bilangan yang disajikan, untuk menemukan suku-suku berikutnya adalah dengan mengurangi suku sebelumnya dengan 4 atau menambahkan suku sebelumnya dengan 6. Subjek S01 menentukan berapa banyak pengurangan dengan 4 dan penjumlahan dengan 6 yang dibutuhkan dari suku pertama untuk mencari suku ke 100.

Menurut indikator penalaran aljabar pada pencarian pola subjek S01 melakukan identifikasi unsur-unsur pola bilangan, yaitu suku-suku pada pola bilangan. Kemudian subjek S01 menggunakannya untuk mencari beda antar suku pada pola bilangan, hal ini menunjukkan bahwa subjek S01 mencoba menemukan hubungan antar unsur pada pola bilangan.

Selanjutnya subjek S01 menemukan kesamaan hubungan setiap elemen penyusun pola bilangan dan melakukan percobaan-percobaan untuk menemukan aturan umum pola bilangan dapat dilihat pada jawaban dan petikan wawancara berikut.

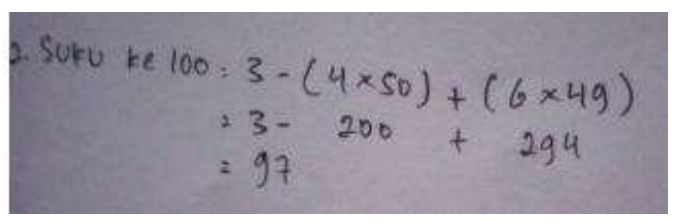

Gambar 2. Hasil Pekerjaan Subjek S01

P : Coba jelaskan caramu mengerjakan soal nomor 2.

S01 : Dicari suku ke 100. Caranya 3-4+6-4+6 terus. -4 50 kali, terus ditambah 649 kali

$\mathrm{P} \quad$ : Kenapa harus -450 kali?

S01 : Kalau mencari suku ke 10 -4 nya ada 5 berarti kalau mencari suku ke 100, -4 nya ada 50.

$\mathrm{P} \quad$ : Terus kenapa $6 \times 49$ ?
S01 : Biar genap 100.

$\mathrm{P}$ : Maksudnya?

S01 : Maksudnya -4 nya ada 50, ditambah 3 (suku pertama) berarti ada 51 biar genap 100 (suku) 6 nya 49.

Dari pemahaman subjek S01 pada soal nomor 2, subjek S01 menggunakan rumus yang sama untuk mencari rumus umum dari pola bilangan. Dalam proses mencari rumus umum dari pola 
bilangan, subjek S01 melakukan percobaanpercobaan untuk mengaitkan hubungan antara urutan suku dan formula yang dimiliki subjek.

Berdasarkan indikator penalaran aljabar, dalam mengenali pola, subjek S01 menemukan adanya pola berulang yang membentuk suku-suku pada pola bilangan. Artinya subjek S01 menemukan kesamaan hubungan setiap elemen penyusun pola bilangan. Berdasarkan pemahaman tersebut, subjek S01 menyederhanakan cara untuk menemukan suku-suku yang lain pada pola bilangan dengan melakukan percobaan-percobaan untuk menemukan aturan umum pola bilangan.Subjek S01 menemukan aturan umum pola bilangan dapat dilihat pada jawaban dan petikan wawancara berikut.

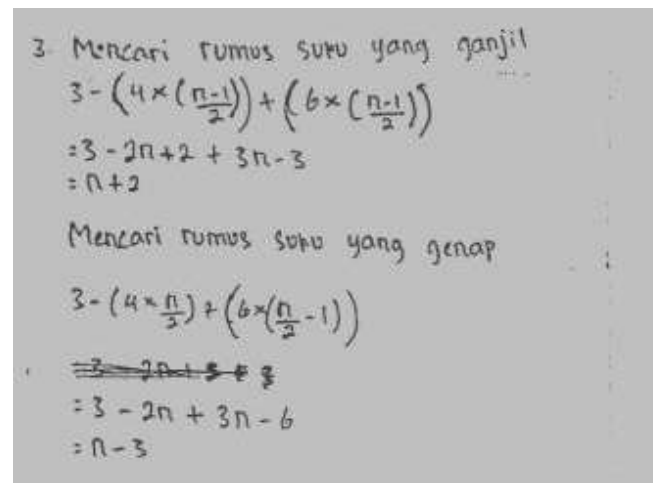

Gambar 3. Hasil Pekerjaan Subjek S01

$\mathrm{P} \quad$ : Bagaimana kamu menemukan rumus pola bilangannya?

S01 : Rumus mencarinya kan 3-4xbanyaknya 4+ 6xbanyaknya 6 . Lha kalau sukunya ganjil angkanya sama mbak

P : Maksudnya angkanya sama?

S01 : Maksudnya kalau 4 dikali 16 dikali 1, kalau 4 dikali 26 dikali 2

$\mathrm{P} \quad$ : Terus langkah selanjutnya?

S01 : Langkah selanjutnya misal suku ke 3, $4 \times$ $1,6 \times 1$, biar bisa dapet 1 caranya (3-1):2. 3 diganti $n$ jadi (n-1):2. Terus tak coba mencari suku lain ternyata bener. Tapi kalau sukunya genap nggak bisa.

$\mathrm{P}$ : Kenapa?

S01 : Soalnya angkanya nggak sama. Misal kalau nyari suku 4, 4×2, $6 \times 1$

$\mathrm{P} \quad$ : Terus gimana?
S01 : Terus kalau sukunya $4,4 \times 2$, kalau sukunya $6,4 \times 3$, setengahnya. Jadi

$$
\frac{n}{2} \text {. }
$$

Berdasarkan pemaparan subjek S01. Menurut indikator penalaran aljabar, pada tahap generalisasi subjek S01 telah menemukan rumus umum atau aturan umum dari pola bilangan pada soal tes yaitu

dan

\section{Subjek S02}

$$
n+2
$$

$$
n-3
$$

Subjek S02 menentukan unsur-unsur penyusun pola bilangan dan hubungan antar unsur dapat dilihat pada jawaban dan petikan wawancara berikut.

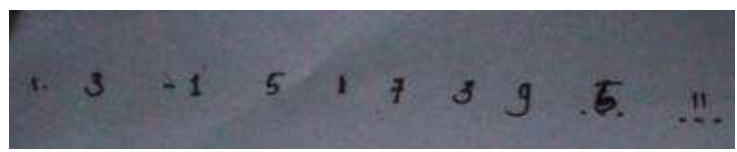

Gambar 4. Hasil Pekerjaan Subjek S02

P : Coba jeaskan caramu mengerjakan soal nomor 1 !

S02 : Cara nomor 1 adalah dengan

$$
\mathrm{n}(7)=\mathrm{n}(6)-4
$$$$
\mathrm{n}(8)=\mathrm{n}(7)+6
$$ 
P : Asalnya kok dikurangi 4 sama ditambah 6 gimana?

S02 : Suku ganjil semua ditambah (-4). Suku genap semua ditambah 6

Langkah pertama yang dilakukan subjek S02 untuk menyelesaikan soal tes yaitu mencari selisih dua suku pada pola bilangan. Kemudian subjek S02 menemukan bahwa semua suku ganjil nilainya ditentukan oleh penambahan suku sebelumnya dengan (-4), sedangkan semua suku genap nilainya ditentukan dengan penambahan suku sebelumnya dengan 6 .
Berdasarkan indikator penalaran aljabar subjek S02 melakukan pencarian pola dengan mengidentifikasi unsur-unsur pola bilangan, yaitu suku-suku pada pola bilangan. Kemudian subjek S02 mencari beda antar dua suku yang berdekatan pada pola bilangan, hal ini menunjukkan bahwa subjek S02 mencoba menemukan hubungan antar unsur pada pola bilangan.

Kemudian subjek S02 mengenali pola dapat dilihat pada jawaban dan petikan wawancara berikut.

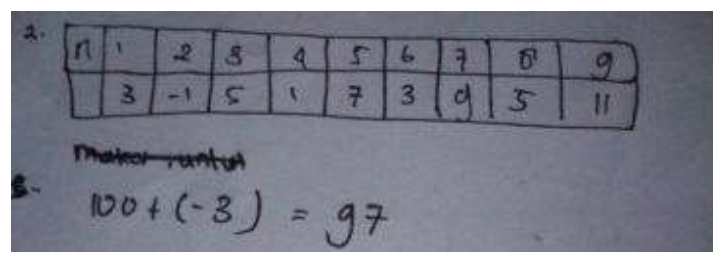

Gambar 5. Hasil Pekerjaan Subjek S02

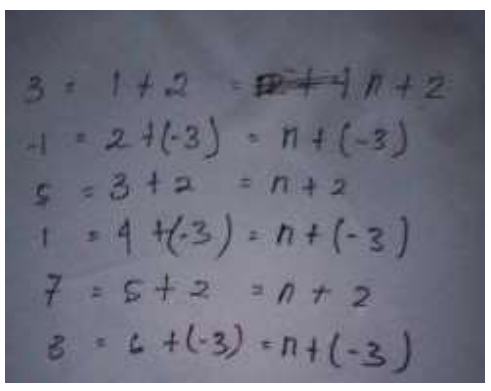

Gambar 6. Hasil Pekerjaan Subjek S02

$\mathrm{P}$ : Caramu mengerjakan nomer 2 gimana?

S02 : Bikin tabel dulu mbak.

$\mathrm{P}$ : Maksudnya tabel itu apa?

S02 : n_1 itu 3, n_2 itu -1, n_3 itu 5 gitu

$\mathrm{P} \quad$ : n itu apa?

S02 : Urutan suku.

$\mathrm{P}$ : Setelah kamu buat tabel, langkah selanjutnya apa?

S02 : Mencari 3 dari 1+2. Sama n+(-3).

$\mathrm{P}$ : Maksudnya?

S02 : Maksudnya kalau mencari 3 itu bisa $n+2$, mencari 5 juga $n+2$, mencari 7 juga $n+2$, ada yang sama

$\mathrm{P} \quad$ : Terus gimana caramu mencari suku ke 100 ?

S02 : Suku ke 100, 100-3=97

$\mathrm{P}$ : Kenapa seperti itu?

S02 : Karena rumusnya sama mencari -1

$\mathrm{P}$ : Kenapa kamu menyimpulkan sama?

S02 : Karena rumus $\mathrm{n}+(-3)$ itu untuk mencari suku ke 2, 4 sama 6. Berarti genap. Suku ke 100 genap jadi mencarinya pakai rumus itu juga
$\mathrm{P} \quad$ : Jadi rumusnya ketemu apa?

S02 : $\mathrm{n}+(-3)$

$\mathrm{P} \quad$ :Kalau mencari suku yang ganjil rumusnya juga $n+(-3)$ ?

S02 : Nggak. $n+2$.

Untuk menemukan suku ke 100 dari pola bilangan, subjek S02 membuat tabel terlebih dahulu kemudian mencari hubungan antara urutan suku dan nilai suku. Subjek S02 mendata sukusuku yang diketahui pada soal dan mengaitkan hubungan nilai suku dan urutan suku (Gambar 6). Subjek S02 menemukan bahwa terdapat dua rumus yang berbeda yaitu $n+2$ dan $n+(-3)$. Subjek S02 mencari suku ke 100 menggunakan rumus $n+(-3)$ karena menyimpulkan bahwa rumus tersebut dapat digunakan untuk mencari semua nilai suku genap pada pola bilangan.

Subjek S02 mencoba rumus yang ditemukan ke suku-suku lain pada pola bilangan. subjek S02 mendata suku-suku yang diketahui pada soal dan mengaitkan hubungan nilai suku dan urutan suku. 
Hal ini yang kemudian mendasari subjek S02 untuk menemukan rumus umum dari pola bilangan.

Berdasarkan indikator penalaran aljabar, dalam mengenali pola, subjek S02 menemukan adanya pola tertentu antara suku ganjil dan suku genap. Berdasarkan pemahaman tersebut, subjek S02 mencoba menemukan rumus umum pola bilangan dengan melihat keterkaitan antara urutan suku dengan nilai suku. Hal tersebut memudahkan
Subjek S02 menyatakan rumusan umum dari pola bilangan yaitu

$$
n+2
$$

untuk menentukan suku pola bilangan yang genap dan

$$
n-3
$$

untuk menentukan suku pola bilangan yang ganjil dalam bentuk kalimat dilihat pada hasil pekerjaan subjek sebagai berikut.

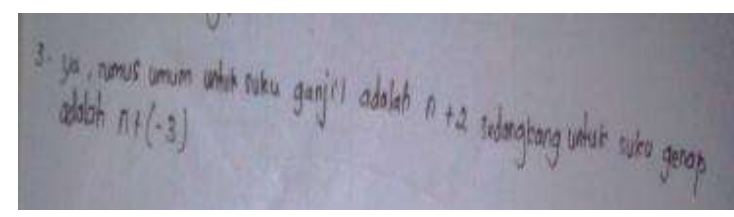

Gambar 7. Hasil Pekerjaan Subjek S02

subjek S02 menemukan nilai suku ke 100 sekaligus menemukan aturan umum dari pola bilangan.

Pada tahap generalisasi subjek S02 telah menemukan rumus umum atau aturan umum dari pola bilangan yaitu $n+2$ untuk suku ganjil dan $n-3$ untuk suku genap

Penalaran aljabar siswa pada indikator mencari pola, siswa menentukan unsur-unsur penyusun pola bilangan yaitu suku-suku pada pola bilangan kemudian menemukan hubungan antar dua unsur penyusun pola bilangan. Pada tahap ini siswa menggunakan cara yang sama yaitu mencari beda antar dua suku yang berdekatan. Setelah mencari beda antar suku siswa menemukan bahwa untuk menentukan suku berikutnya terdapat dua cara yaitu menambahkan dengan 6 atau -4 . Dengan cara tersebut siswa dapat dengan mudah mencari dua suku selanjutnya dari pola bilangan pada soal tes.

Melalui proses pencarian beda antar suku, siswa masuk pada tahap kedua penalaran aljabar yaitu siswa menyadari bahwa ada pola tertentu yang menyusun pola bilangan tersebut yang artinya siswa menemukan kesamaan hubungan setiap unsur penyusun pola bilangan. Dalam hal ini siswa mengelompokkan unsur penyusun pola bilangan menjadi suku ganjil dan suku genap. Hal ini sesuai dengan penelitian Kobandaha (2019) bahwa pada tahap mengenali pola siswa mencari hubungan antar unsur penyusun pola dan menemukan kesamaannya.

Untuk mencari suku yang besar seperti suku ke 100 pada soal kedua, siswa berpikir untuk menemukan rumusan umum, mencoba terhadap suku-suku yang diketahui, sehingga memudahkan mereka untuk mencari suku ke 100. Hal yang sama juga dinyatakan Herbert dan Brown (2000) bahwa pada saat memecahkan masalah aljabar, ketika siswa diminta untuk mencari nilai yang besar dalam suatu pola, siswa akan termotivasi untuk mencari aturan umum dan mencobanya pada kasus yang nilainya kecil. Dalam hal ini siswa menemukan rumus dengan cara yang berbeda. Salah satu siswa menggunakan dasar hubungan antar suku yang ia temukan sebelumnya dan membuat dugaan untuk menemukan suku ke 100. Sedangkan siswa yang lain menggunakan cara yang berbeda dengan cara sebelumnya, dengan kata lain ada siswa yang tidak lagi menggunakan temuannya pada soal pertama untuk mencari suku yang lebih besar, melainkan membuat dugaan dengan cara lain yaitu memunculkan $n$ yang merepresentasikan urutan suku dan mencoba mencari aturan umum pola bilangan dari mengamati keterkaitan antara urutan suku dan nilai suku. Terdapat kesamaan hasil penelitian ini dengan penelitian sebelumnya oleh Indraswari (2018) bahwa pada tahap pengenalan pola siswa memunculkan dugaan-dugaan terkait aturan umum dari pola tersebut.

Siswa yang tetap menggunakan temuan pertama untuk mencari aturan umum pola bilangan baru memunculkan $\mathrm{n}$ ketika diminta mencari aturan umum dari pola bilangan tersebut yang mana membutuhkan proses yang lebih panjang untuk berpindah dari tahap mengenali pola menuju tahap generalisasi. Sedangkan siswa lainnya menemukan nilai suku ke 100 sekaligus aturan umum dari pola bilangan tersebut. Namun kedua siswa berhasil menggeneralisasi pola bilangan tersebut dengan menemukan aturan umum pola bilangan yaitu $n+2$ untuk suku genap dan $n-3$ untuk suku ganjil.

\section{Simpulan}

Berdasarkan hasil penelitian dan pembahasan, dapat disimpulkan bahwa terdapat dua tipe 
penyelesaian yang dilakukan siswa dalam menyelesaikan soal pola bilangan yaitu, tipe pertama, mengikuti ide awal untuk menentukan generalisasi, dan tipe ke dua, menemukan ide baru untuk menggeneralisasi pola bilangan. Penalaran aljabar siswa yang menyelesaikan soal pola bilangan mengikuti ide awal untuk menentukan generalisasi, mencari pola diawali dengan mengidentifikasi unsur penyusun pola bilangan kemudian siswa menemukan hubungan tiap unsur pada pola bilangan. Pada tahap mengenali pola, siswa menyadari bahwa terdapat kesamaan hubungan antar suku-suku ganjil dan suku-suku genap pada pola bilangan. Kemudian siswa melakukan percobaan-percobaan untuk menemukan rumus umum pola bilangan agar memudahkan untuk mencari nilai tiap suku. Pada tahap generalisasi, siswa menarik kesimpulan dari proses yang dilakukannya di tahap sebelumnya. Sedangkan penalaran aljabar siswa yang memunculkan ide baru dalam menyelesaikan soal pola bilangan, pada saat mencari pola diawali dengan mengidentifikasi unsur penyusun pola bilangan kemudian siswa menemukan hubungan tiap unsur pada pola bilangan. Pada tahap mengenali pola, siswa menggunakan tabel dan melakukan pendataan tiap suku pada pola bilangan untuk menemukan rumus umum pola bilangan sebelum melakukan percobaan-percobaan untuk menemukan rumus umum pola bilangan. Pada

\section{Daftar Pustaka}

Ayal, C. S dkk. 2016. The Enhancement of Mathematical Reasoning Ability of Junior High School Students by Applying Mind Mapping Strategy. Journal of Education and Practice. Vol. 7(25): hal. 50-58.

Chow, T.C. Francis. 2011. Students'Difficulties, Conception, and Attitudes Towards Learning Algebra: An Intervention Study to Improve Teaching and Learning. Tesis. Australia: Curtin University.

Guner P., Ersoy E. dan Temiz, T. 2013. 7th and 8th Grade Students, Generalization Strategies of Patterns. International Journal of Global Education 2013. Vol. 2 (4): hal 38-54.

Herbert, Kristen dan Brown, R. H. 2000. Patterns as Tools for Algebraic Reasoning. Algebraic Thinking, Grades K-12 Reasings from NCTM's School-Based Journals and Other Poblication. Vol 3 (6): hal. 123-128.

Indraswari, N. F. 2017. Penalaran Aljabar Siswa SMP dalam Menyelesaikan Masalah Matematika Ditinjau dari Gaya Belajar. Tesis tidak diterbitkan. Surabaya : Universitas Negeri Surabaya.

Istiqomah, Nisa R. 2016. Penalaran aljabar siswa langkah akhir penalaran aljabar yaitu generalisasi siswa menarik kesimpulan dari proses yang dilakukannya di tahap sebelumnya.

\section{Saran}

Saran yang dapat diberikan peneliti sebagai berikut.

1. Pada hasil penelitian, peneliti menemukan bahwa terdapat perbedaan penalaran pada proses mengenali pola, yaitu terdapat siswa yang memunculkan ide baru untuk mencoba mencari aturan umum dari pola bilangan dimana siswa yang lain mencari aturan umum pola bilangan berdasarkan kesamaan hubungan antara dua unsur pola bilangan. Hal ini dapat dikaji lebih dalam pada penelitian selanjutnya terkait pengetahuan awal siswa penyebab perbedaan tersebut.

2. Sebaiknya guru lebih memperhatikan proses siswa mengenali pola terutama pada saat siswa melakukan percobaan untuk menemukan aturan umum pola bilangan. Hasil penelitian menemukan adanya perbedaan cara untuk menemukan aturan umum pola bilangan. Hal ini tentunya berkaitan dengan kreativitas siswa dalam menyelesaikan soal. Pada tahap mengenali pola, guru dapat membimbing siswa untuk menemukan lebih banyak cara untuk menemukan aturan umum dari pola bilangan.

SMA dalam menyelesaikan masalah matematika berdasarkan gaya kognitif. Tesis tidak diterbitkan. Surabaya: Universitas Negeri Surabaya.

Kaput, J. dan Blanton, M. 2005. Characterizing a Classroom Practice That Promotes Algebraic Reasoning. Journal for Research in Mathematics Education. Vol 36 (5): hal. 412446.

Kobandaha, P. E. 2019. Penalaran Aljabar Siswa Logical-Mathematical Intelligence dan Visual-Spatial Intelligence dalam Menyelesaikan Soal Aljabar. Tesis tidak diterbitkan. Surabaya : Universitas Negeri Surabaya.

Lee, Y. dkk. 2018. A Meta-Analysis: Improvement of Students' Algebraic Reasoning through Metacognitive Training. Journal International Education Studies. Vol 11(10): hal. 42. doi: 10.5539/ies.v11n10p42.

Lew, H. C. 2004. Developing algebraic thinking in the earlier grades: A case study of the South Korean elementary school mathematics curriculum. Journal ZDM- International Journal of Mathematics Education. Vol 8 (1): hal. 88-106. Singapore. 
Lepak, J. R., Wernet, J. L. W. and Ayieko, R. A. 2018 Capturing and characterizing students' strategic algebraic reasoning through cognitively demanding tasks with focus on representations. Journal of Mathematical Behavior. Vol. 50: hal. 57-73. doi: 10.1016/j.jmathb.2018.01.003.

Lohman, D., \& Lakin, J. 2011. Intelligence and Reasoning. Dalam R. Sternberg \& S. Kaufman (Eds) The Cambridge Handbook of Intelligence Chapter 21: hal. 419-441.

Mulligan, J., Cavanagh, M. and Keanan-Brown, D. 2012. The role of algebra and early algebraic reasoning in the Australian Curriculum: Mathematics. B. Atweh, M. Goos, R. Jorgensen, \& D. Siemon (Eds) Engaging the Australian National Curriculum: Mathematics- Perspective From The Field: hal. 47-70.

Permana, Y., dan Sumarmo, U. 2007. Mengembangkan Kemampuan Penalaran dan Koneksi Matematik Siswa SMA Melalui Pembelajaran Berbasis Masalah. Jurnal Educationis. Vol 1 (2): hal 116-122.

Rivera, F. D. dan Becker, J. R. 2009. Algebraic reasoning through patterns. Journal Mathematic Teaching in The Middle School vol 15 no 4. NCTM.

Rosnawati, R. 2013. Kemampuan Penalarn Matematika Siswa SMP Indonesia pada TIMSS 2011. Makalah disampaikan dalam Prosiding Seminar Nasional Penelitian, Pendidikan, dan Penerapan MIPA,

Shadiq, Fajar. 2004. Pemecahan Masalah, Penalaran dan Komunikasi. Disampaikan pada Diklat Instruktur/ Pengembang Matematika SMA Jenjang Dasar, Yogtakarta, 6-19 Agustus 2004.

Sukirwan, Darhim, dan T. Herman. 2018. Analysis of Student's Mathematical Reasoning. Journal of Physics: Conf. IOP. Series 948: hal. 1-7.

Tanisli, Dilek \& Ozdas, Aynur. 2009. The Strategies of Using the Generalizing Patterns of the Primary school 5th Grade Students. Journal Educational Sciences: Theory and Practice. Vol 9 (3): hal. 1485-1497. Turki: Yunus Emre Campus, Eskişehir.

Wardhani. S. dan Rumiati. 2011. Instrumen Penilaian Hasil Belajar Matematika SMP: Belajar dari PISA dan TIMSS. Yogyakarta: PPPPTK Matematika.Yogyakarta, 18 Mei 2013Acar Sesen, B., \& Tarhan, L. (2013). Inquiry- Based Laboratory Activities in Electrochemistry: High School Students' Achievements and Attitudes. Research in Science Education, 43(1), 413-435. 